\title{
Integrated HS and ALS Remote Sensing Data Sources to Develop Green Corridors in Sopron Mountains
}

\author{
János Tamás ${ }^{1}$, Éva Bozsik ${ }^{2}$, Péter Riczu ${ }^{3}$, Bernadett Gálya ${ }^{4}$, Miklós Herdon ${ }^{5}$, Stelian Nistor ${ }^{6}, J^{\prime} n o s$ \\ Fehér $^{7}$, Charles Burriel ${ }^{8}$, Herman Heilmeier ${ }^{9}$
}

\section{N F O}

Received 28 Aug 2014

Accepted 1 Oct 2014

Available on-line 6 Oct 2014

Responsible Editor: K. Rajkai

\section{Keywords:}

remote sensing, hyperspectral imaging, LiDAR survey, agroforestry, green corridor

\begin{abstract}
A B S T R A C T
The green corridors are part of the European Union rural landscapes, but the regional increase in size of agricultural parcels had a significant effect on European land use in the $20^{\text {th }}$ century. This effect radically reduced the coverage of natural forest. One ecological problem with the remaining forests is the partial missing of the network connecting the parts with ecological green corridors. Another economical problem is the verifiability for the payment system of agroforestry. Remote sensing methods are currently used to supervise monitoring the arable lands, plantations, natural reserve areas, as well as to help for the European Union payment system. Nowadays the airborne hyperspectral (HS) and LiDAR (Light Detection And Ranging; ALS) remote sensing technologies are becoming of more widespread use. They can be applied especially in spatial decision support system (SDSS), used in decisions about for nature, environment, forests, agriculture protection, conservation and monitoring, as well as for monitoring of biomass production. Our site selection model was the first step towards planning an agroforestry plantation which uses these integrated technologies to connect the parts with green corridors.
\end{abstract}

\section{Introduction}

Many definitions have been proposed, but generally agroforestry land use systems means an ecologically mixed land use, where woody plants (trees, shrubs, palms, bamboos etc.) are consciously combined with arable crops and/or livestock farming on the same land use unit, which practice can function as green corridors. In this land use system there are both ecological and economical interactions between the different components (Lundgren and Raintree 1982). The generally

\footnotetext{
${ }^{1}$ János Tamás ${ }^{1}$

University of Debrecen, 4032, Debrecen, Böszörményi út 138, Hungary

tamas@agr.unideb.hu

2 Éva Bozsik

University of Debrecen, , 4032, Debrecen, Böszörményi út 138, Hungary

eva.bozsik@agr.unideb.hu

${ }^{3}$ Péter Riczu

University of Debrecen, , 4032, Debrecen, Böszörményi út 138, Hungary

riczu@agr.unideb.hu

${ }^{4}$ Bernadett Gálya

University of Debrecen, , 4032, Debrecen, Böszörményi út 138, Hungary

bernadett.galya@agr.unideb.hu

${ }^{5}$ Miklós Herdon

University of Debrecen, , 4032, Debrecen, Böszörményi út 138, Hungary

herdon@agr.unideb.hu

${ }^{6}$ Stelian Nistor

University of Oradea, C.P. nr. 114, Oficiul Postal 1, str. Universitatii nr. 1, Oradea, Romania

snistor@uoradea.ro

7 János Fehér

University of Debrecen, , 4032, Debrecen, Böszörményi út 138, Hungary

janos.feher@famife.hu

${ }^{8}$ Charles Burriel

AGROSUP, 26, boulevard Docteur-Petitjean BP 8799921079 Dijon, France

charles.burriel@educagri.fr

${ }^{9}$ Herman Heilmeier

TU Bergakademie Freiberg, Institut für Biowissenschaften, Leipziger Str. 29 09599, Freiberg, Germany, hermann.heilmeier@ioez.tu-freiberg.de
}

ISSN 2061-862X (http://www.magisz.org/journal)

János Tamás, Éva Bozsik, Péter Riczu, Bernadett Gálya, Miklós Herdon, Stelian Nistor, János Fehér, Charles Burriel,

Herman Heilmeier: Integrated HS and ALS Remote Sensing Data Sources to Develop Green Corridors in Sopron Mountains 
worldwide used practices are alley cropping, windbreaks, forested riparian buffer strips, silvopasture, forest farming, and whole farm diversification with woody crops. The green corridors can be part of agroforestry practices helps to conserve and protect natural resources by low carbon and high biomass productive agriculture (EURAF). One real - ecological - problem with these forests is the partly missing of network function without connecting ecological green corridors. The other - economical problem is verifiability for the agroforestry payment system, monitoring the arable lands and plantations.

Remote sensing methods are currently used to supervise European Union payments for vineyards and olive groves (e.g. in Italy, Spain, Portuguesa, French and Greece). With these methods could be used to help distinguish agroforestry areas from forest. Technology exists and is rapidly improving for automatic counting of trees from these images. We can use remote sensing technology for monitoring of agro-environment areas such as \% arable land covered (e.g. soil/no soil), buffer strips and margins, land use, land cover, burning, harvest dates, hay cutting dates, cover crops dates, irrigation by flooding, etc (Lawson et al. 2005). Nowadays, next to use satellite imagery the airborne hyperspectral and LiDAR (Light Detection And Ranging) remote sensing technologies are becoming more widespread use for nature, environmental, forest, agriculture protection, conservation and monitoring and it is an effective tool for monitoring biomass production (Curran 1981, Kale et al. 2002). Passive (hyperspectral) and active (LiDAR) remote sensing methods can acquire information about larger areas at the Earth's surface, without being in direct physical contact with the object area (Aggarwal 2004).

\section{Materials and methods}

The study area of the model was carried out in part of West Hungary (near Sopron, extension part of the east Alps) which is about 2350 hectares area. Based on CORINE Landcover (CLC2006), DTA50 (Topological map of the Hungarian Republic in 1:50.000 scale) database the main land use classes were specified in different land use categories: arable land (clc06_c211), pasture (clc06_c231), forest, built-up area (city of Sopron, town of Ágfalva), farm, watercourses, channels, roads (dirt and highway). The study area contains part of the Sopron Mountains which is part of Natura2000 habitat sites in Europe.

\subsection{Airborne hyperspectral survey and data}

The airborne surveys of the study area were carried out within the framework of ChangeHabitats2 project. Important aim of this project to evaluate the advantages of the novel hyperspectral and LiDAR technology for habitat mapping, biodiversity monitoring, environmental and nature conservation in NATURA 2000 habitat sites.

Hyperspectral remote sensors collect data of surface in hundreds of narrow, adjacent spectral bands. This imagery is an effective tool to detect material quality characteristics of objects (e.g. different plant species) and could provide relatively more information that multispectral imaging (Smith 2006). The hyperspectral data was acquired by AISA DUAL hyperspectral imaging system. The two sensors - AISA Eagle and Hawk - are assembling in one house. The Eagle can perceive in the visible and near infrared ranges (400-1300nm), the Hawk can process in short wave infrared ranges (1300-2500nm). The system has a so-called push-broom hyperspectral imagery sensor with fibre optic radiation meters (FODIS), which collect information about the incoming light.

Certain reflectance values in the electromagnetic radiation are useful to create vegetation indices, which correlate with the changes in biomass (Silleos et al. 2006). Plants reflect the visible (VIS) band 
but in the near infrared (NIR) the reflectance increases depend on the chlorophyll content of leaves. Using the reflection from the RED (630-690 $\mathrm{nm}$ ) and the NIR bands $(760-900 \mathrm{~nm})$, the green mass may be defined by the Normalized Difference Vegetation Index (NDVI):

$$
\mathrm{NDVI}=\left(\mathrm{R}_{\mathrm{NIR}}-\mathrm{R}_{\mathrm{RED}}\right) /\left(\mathrm{R}_{\mathrm{NIR}}+\mathrm{R}_{\mathrm{RED}}\right)
$$

Thanks to NDVI - whose value varies between -1 and 1 - we can separate easily from each other the dense vegetation and non vegetation areas. Naturally it is also possible to determine the sparse vegetation or moderate vegetation, but in our case we calculated only with the areas extension of dense and non vegetation. The NDVI image processed in ENVI 5.0 software used Vegetation Delineation tool. This tool identified the presence of vegetation and visualized the vigor levels of it.

\subsection{Airborne LiDAR survey and data}

Laser scanning is an active surveying technology for obtaining detailed - elevation, structural information about the land surface. Result of the survey generates a point cloud consisting of millions of points, with evaluation value of each point. This point cloud useful to get spatial $3 \mathrm{D}$ information about the objects, surfaces. High laser point density provides to create high resolution digital elevation model (DEM) or digital surface model (DSM) (Wagner 2007, Fórián 2012). The LiDAR image was created by RIEGL LMS-Q680i full waveform laser scanner. The scanned area was approximately 90 $\mathrm{km}^{2}$, which made in 22 flight stripes, contains more than 530 million laser points with $9.83 \mathrm{pts} / \mathrm{m}^{2}$ average point density During the survey seven return pulses (first, second, last, single, first-of-many, second-of-many, third-of-many, last-of-many returns) and four LiDAR point classes (unclassified, ground, medium vegetation, high vegetation) were identified. The LiDAR image was evaluated in GlobalMapper 15.0 and ArcGIS 10.2 software.

\subsection{The Spatial Decision Supporting System (SDSS)}

The applied Spatial Decision Supporting System used two types criteria: constraints and factors. Constraints are those logical criteria that limit our analysis, so 1 or 0 Boolean logical value is added to each investigated decision factors. In our case, this logical values were ideal for distinguish land use areas, which could be suitable or unsuitable for forestation under any condition. Factors are criteria that define some degree of suitability for all geographic regions.

ArcGIS 10.2 software was used to create the site selection model for determined the potential areas of forestation. In generally in the most geographic region important factors are the elevation of the surface, hydrological conditions and soil type. 


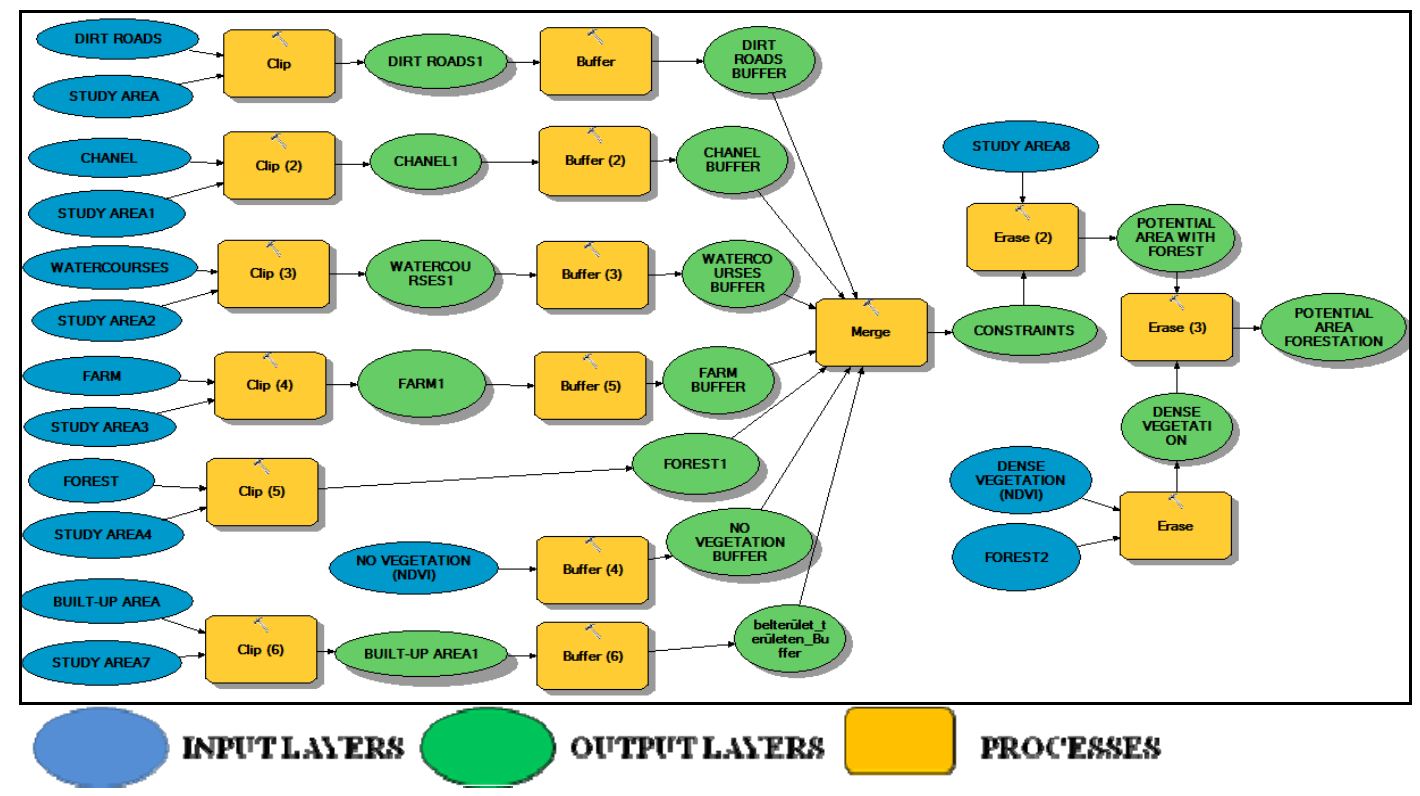

Figure 1. SDSS model of the site selection

In this case of our conceptual model building the constraint layers were: forest, built-up area, farm, watercourses, channels, dirt and highway roads (Figure 1). These land uses cannot be directly forested but in the immediate vicinity of them the forestation can be done - if there are no other limitation constraints. Thus we created uniformly a 10 meters buffer zone around areas and then we merged them into one "Constraints" layer, and erased out from the study area. The other constraint of the forestation was the dense vegetation (without forest, because earlier it was involved into constraints) based on NDVI. Dense vegetation most probably also contains tree hedges, isolated trees, shrubs etc. that cannot be classified into forest land use. Similarly the merged constrains dense vegetation has erased out from the area. Dense vegetation of pastures and arable land has calculated separately in order to determine the extension of the potential forestation sites there.

\section{RESULTS AND DISCUSSIONS}

\subsection{Results of airborne hyperspectral analysis}

We used the four basic classes: no vegetation ( 0 value), sparse ( 0.25 value), moderate ( 0.5 value) and dense $(0.7$ - 1 value) vegetation. Typically the no vegetation contains dirt roads, highway, buildings, bare soil. Into the sparse and moderate vegetation can be classified the weedy area, grasslands, and dense vegetation collected the forest areas, tree hedges, isolated trees, shrubs and sown area (Figure 2). In bare soil could be vegetation, so we segmented that areas. In the sown we also can make forestation but the software detected this areas like forests, based on NDVI value. Due to we calculated with their area extension during the investigation and added to the potential area sites. 


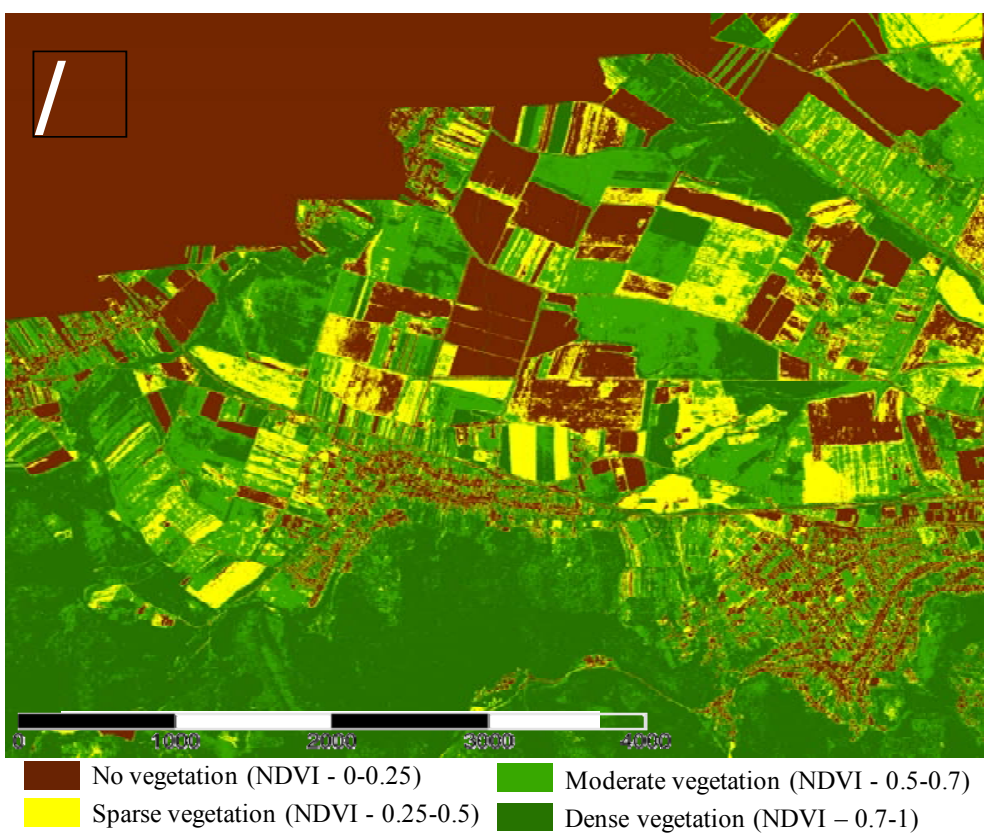

Figure 2. NDVI image of the study area

\subsection{Results of airborne LiDAR analysis}

The LiDAR image was used to create a DEM of study area. Thanks to LiDAR survey we could get the high values of the area in every laser point from which could make DEM and work in 3D. The importance of this kind of remote sensing technology is extremely high, because it is suitable for inter alia measure the high of trees, forecast estimate the biomass production, and create the runoff conditions in a large extension of area. We created the digital elevation model in the end we compared it with the potential sites of forestation (Figure 3).
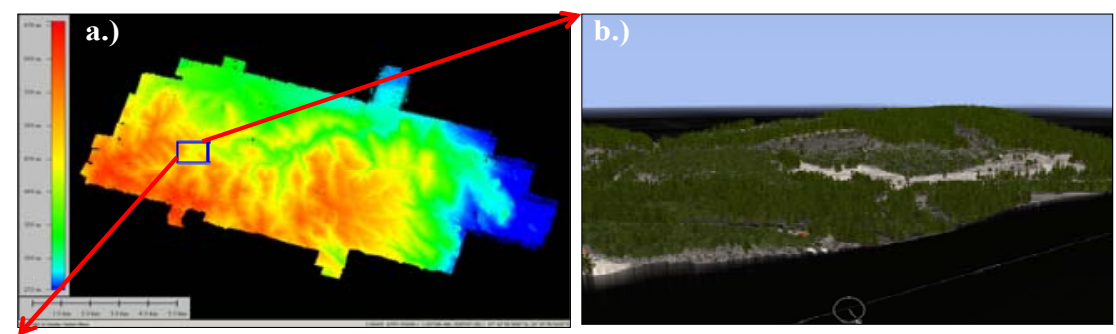

c.)

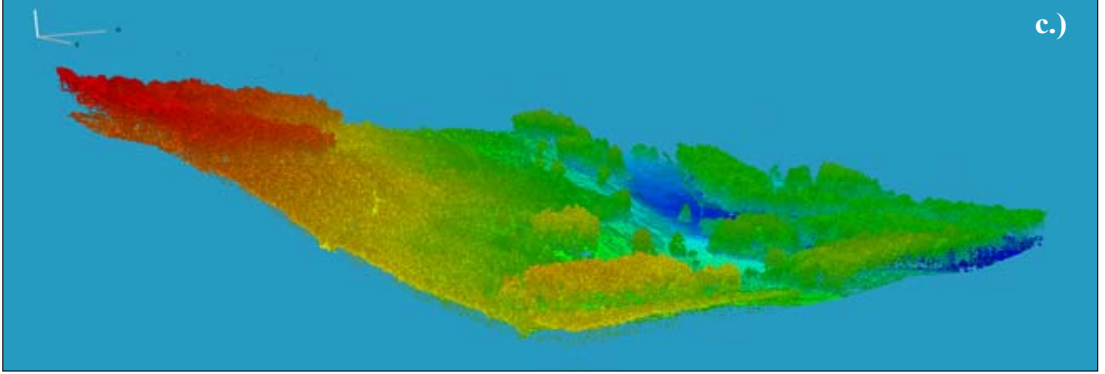

Figure 3. a.) DEM; b.) c.) 3D slice of the study area based on LiDAR image

\subsection{Results of Spatial Decision Supporting System (SDSS)}

Determined the constrains and factors, the model was run and we have received the potential sites for forestation (Figure 4). 


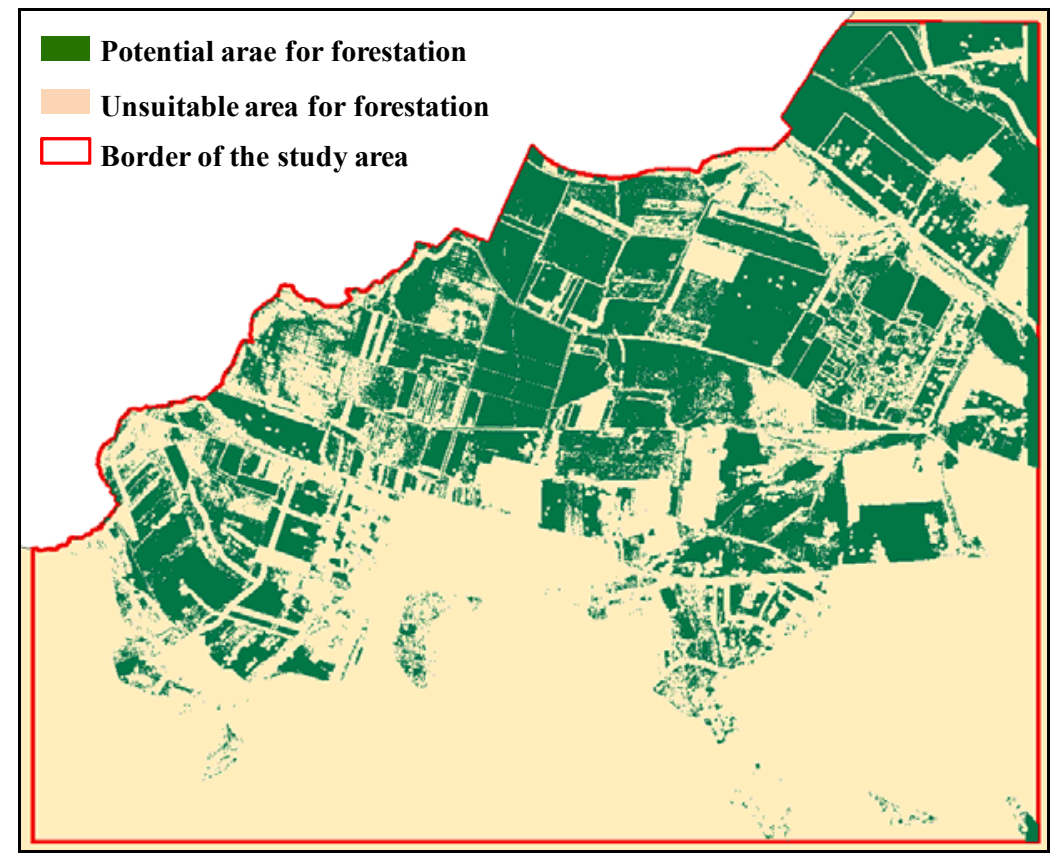

Figure 4. Result of the site selection model

The large part of the potential tree-planting areas are located in lower surface levels (about 250-400 meter) in the arable lands, pastures and parallel with roads. Smaller part of potential sites can be found in higher levels (about 400-550 meter), in the hillside. The areas of potential sites in hectares are shown in Table 1.

Table 1. Currently and potential forestation areas in the study area

\begin{tabular}{|l|c|c|}
\hline Land use category & Area (ha) & Potential forestation (ha) \\
\hline Forest & 755 & 12 \\
\hline Arable land & 797 & 797 \\
\hline Pasture & 343 & 219 \\
\hline City/town & 412 & 0 \\
\hline Farm & 20 & 0 \\
\hline Total & 2327 & 1028 \\
\hline
\end{tabular}

\section{CONCLUSION}

Based on the results of SDSS and taking into consider of field experts we suggested the following species for plantation: in the hillside sessile oak, hornbeam, scots pine; into the lower surface birch, poplar, elm, and ash tree etc. species. Taking into consideration the criterions of national "First establishment agroforestry system" support fund we are not entitled for support in case of conifer plantation, woody plantations for energy purposes, sick, comma plantation and state-owned area above $50 \%$. At all events planting native tree species according to geographical.

Based on the results of site selection model we concluded that remote sensing technology clearly integrated into process of agroforestry planning, and effectively use for supervise payments.

Increasingly large numbers of countries across Europe are using these technologies which will get important role during the spread of agroforestry systems. This site selection model was the first step of an agroforestry plantation which use these integrated technologies to connect with each other the green corridors. 


\section{Acknowledgement}

This study was supported by EU Leonardo-AgroFE and EU FP7 Marie Curie ChangeHabitats2 projects.

\section{References}

Aggarwal S. 2004. Principles of Remote Sensing. [In. Sivakumar M. V. K., Roy P. S., Harsen K., Saha S. K. (eds.): Satellite Remote Sensing and GIS Applications in Agricultural Meteorology.] World Meteorological Organisation, Geneva: 23-38.

Curran P. J. 1981. Multispectral remote sensing for estimation of biomass and productivity. [In.: Smith, H. (eds.): Plants and the Daylight Spectrum.] New York Academic Press: 65-69.

Fórián T., Nagy A., Riczu P., Tamás J., Heilmeier H. 2012. LIDAR based digital elevation modelling at NATURA 2000 site. [In: Celkova, A. (ed.): Proceedings of peer-reviewed contributions. 20th International Poster Day Transport of Water, Chemicals and Energy in the Soil-Plant-Atmosphere System.] Institute of Hydrology, Slovak Academy of Sciences. 2012. november 15. Bratislava. Slovakia. 165-170. ISBN:978-8089139-28-6.

Kale, M. P., Singh, S. and Roy, P. S. 2002. Biomass and productivity estimation using aerospace data and Geographic Information System. Tropical Ecology. 43 (1): 123-136.

Lawson, G; Dupraz C; Liagre, F; Moreno, G; Paris, P, Papanastasis, V. 2005. Options for Agroforestry Policy in the European Union. Quality of Life and Management of Living Resources, Silvoarable Agrofrestry For Europea (SAFE), European Research contract QLK5-CT-2001-00560, www1.montpellier.inra.fr/safe/

Lundgren, B.O; Raintree J.B. 1982. Sustained agroforestry. In: Nestel B. (ed). Agricultural Research for Development: Potentials and Challenges in Asia. ISNAR, The Hague: 37-49.

Silleos, N. G., Alexandridis, T. K., Gitas, I. Z. and Perakis, K. 2006. Vegetation indices: Advances made in biomass estimation and vegetation monitoring in the last 30 years. Geocarto International. pp 21 (4): 21-28

Smith, R. B. 2006. Introduction to Hyperspectral imaging with TNTmips ${ }^{\circledR}$. MicroImages Tutorial Web site: http://www.iro.umontreal.ca/ mignotte/IFT6150/ComplementCours/HyperspectralImageryIntroduction.pdf Webpage visited: 11.01.2013. Lincoln, Nebraska: 24.

W. Wagner, A. Roncat, T. Melzer, A. Ullrich 2007. Waveform analysis techniques in airborne laser scanning. IAPRS Volume XXXVI (Part 3 / W52): 413-417.

European Agroforestry Federation (EURAF) http://www.agroforestry.eu/node/287 